\title{
Analysis of Structural Transformation in Agricultural Sector in Indonesia
}

\author{
Abdul Aziz*, Ragimun \\ Fiscal Policy Agency, Ministry of Finance, Republic of Indonesia \\ kingabaz@gmail.com*, ragimun@gmail.com
}

\begin{abstract}
Indonesia's economy is currently undergoing a sharp shift of structural transformation. This is evident from the change in the proportion of major sectoral contributions to GDP in Indonesia. The agricultural sector in 2000 accounted for 15.60 percent of the national GDP. This sector is experiencing a gradual downward trend in 2015 which only contributes 12.18 percent. On the other hand there is an increasing contribution to GDP for the trade sector from 16.15 percent in 2000 to 18.06 percent by 2015. The study aims to identify the structural transformation of the agricultural sector in Indonesia, identify fiscal policy, appropriate development programs and can be implemented. The research methodology used is to explore the theory and implementation of several other countries by using SWOT analysis. The results of this research analysis found that the shift of structural transformation in the agricultural sector has the potential to cause negative impacts on several macroeconomic indicators such as GDP per capita persector and workforce of the sector. Therefore, there are several fiscal instruments that can be recommended, among others through credit programs such as Credit for Business Programme, subsidies and agricultural credit. Moreover, it can be done through agricultural insurance schemes and programs to increase infrastructure spending in agriculture so that the structural transformation is expected to keep Indonesia's economic growth more inclusive.
\end{abstract}

Keywords: Transformation, Agricultural Sector, Fiscal Policy, Economic Growth

\section{Introduction}

Indonesia is an agrarian country with a large proportion of its population dependent on the agricultural sector. The agricultural sector is the mainstay sector that accounts for half of Indonesia's economy through foreign exchange contributions on exports of rubber, coffee, cocoa, tea and palm oil products. While the plantation is a provider of employment in rural and remote areas, and is a significant employer absorber. Currently the Indonesian economy is undergoing a sharp shift or structural transformation. This can be seen from the major sectoral contribution to GDP in Indonesia. The significant changes in sectoral contribution to GDP from 2000 to 2015 are the contribution of the Agriculture and Mining sector which shows a downward trend year after year. The agricultural sector in 2000 contributed 15.60 percent to the national GDP. However, this sector experienced a gradual downward trend until 2015 which became only 12.18 percent of total GDP. Similarly, the mining sector experienced a drastic downward trend in 2000 of 12.07 percent to only 6.74 percent in 2015.

On the other hand, there is a gradual increase in the contribution of the trade sector to GDP from 16.15 per cent in 2000 to 18.06 per cent by 2015. In the transport sector there has been a significant contribution to GDP from 4.68 per cent in 2000 to 10.78 percent by 2015. This is the question, why this happens. Whether for the primary sectors in general will experience a downward trend over time and instead the technology-based (tertiary) sectors will generally increase its contribution to Indonesia's GDP as well as the trade and transport sectors. How do other countries experience a shift in structural transformation? Is there any relation to structural transformation with economic growth and how the impact of structural transformation on macro indicators such as labor, poverty and per-capita income of the sector. Furthermore, how the role of government in managing this structural transformation through fiscal policy instruments that become its authority. The expected benefits of this study are that descriptions and clear impacts related to the structural transformation of the agricultural sector in Indonesia can be made, so that the Government can adopt appropriate policies to optimize economic benefits and eliminate the negative impacts.

\section{Literature Review}

Structural Transformation and Growth: Structural Change Theory is a theory that focuses on the mechanisms of economic transformation experienced by developing countries, which was originally more 
subsistence and focused on the agricultural sector to the structure of a more modern economy and is dominated by industry and service sectors. (Todaro: 1991 in Mudrajad Kuncoro: 1997 in Sudarmono: 2006). Herrendorf et al. (2013) said that "the level of employment shares, value added shares, and final consumption expenditure shares. Employment shares are calculated by work by sector, depending on availability. Value added shares and final consumption expenditures are typically expressed in current prices ("nominal shares"), but they may be expressed in constant prices ("real shares"). They argue that there is a strong link between structural transformation and a country's economic development, labor productivity, number of hours worked, business cycle, income inequality, and others. Basically, economic development has four main dimensions: (1) growth, (2) poverty alleviation, (3) economic change or transformation, and (4) sustainable development of agrarian society into industrial society. Structural transformation is a prerequisite of the improvement and sustainability of growth and poverty alleviation, as well as support for the sustainability of development itself. Development in Indonesia has succeeded in spurring high economic growth, marked by changes in the structure of the economy. The process of changing the structure of the economy is characterized by: (1) the decline in the share of the primary sector of agriculture, (2) the increasing share of the secondary sector ie industry, and (3) the share of the tertiary sector (services) is more or less constant, but its contribution will increase in line with economic growth (Kariyasa, 2017).

Lessons Learned From Vietnam, Ethiopia and OECD Countries: Over the last 20 years Vietnam's economy has experienced high growth rates. Real GDP increased at an average annual growth rate of 7 percent between 1986 and 2008. This economic expansion is accompanied by a drastic shift in the composition of Vietnam's GDP, from the agricultural sector to the services and manufacturing sectors. The most drastic changes occur in the agricultural and manufacturing sectors. The agricultural sector accounted for 34 percent of GDP in 1986, but after that its contribution declined steadily to the level of 17 percent in 2009. On the other hand, the manufacturing sector experienced a significant growth of 17 percent in GDP in 1986 and then up to 25 Percent of GDP in 2009, exceeding the share of agriculture in 2003 (Mc Caig and Pavcnik, 2013). The service sector accounts for the largest GDP, with contributing 46-54 percent during the period. Mining and excavation never accounted for more than 6 percent of GDP. Vietnam also experienced a large expansion of labor, an annual average labor increase of 2.4 percent, accompanied by drastic changes in the employment structure. Major shifts occurred in the sectoral composition of Vietnam's GDP and the role of structural change in Vietnamese economic development in the 1990s and 2000s. Vietnam began measuring the contribution of structural change to the growth of aggregate labor productivity. Vietnam found that the reallocation of labor from agriculture to service and manufacturing industries, all sectors with relatively higher labor productivity, played an important role.

In 1986 Vietnam started a series of reforms known as Doi Moi, or "renovation", gradually transforming the economy from central planning to regulating the market economy. The key role of reforms in agriculture, the business sector, and integration of Vietnam into the global economy can contribute to the shift of labor from the agricultural sector. These reforms have the potential to affect not only the movement of labor from the agricultural sector to manufacturing and services, but also the allocation of labor to home industries, stateowned enterprises, foreign-owned enterprises, and private sector companies. Another case with Ethiopia. Some reasons why Ethiopia requires structural transformation. The first reason is related to the growth of the labor force and the increased surplus of agricultural employment that must be diverted to nonagricultural work. Each year there is a new labor force and is estimated to be about four hundred thousand people. The second reason why Ethiopia requires structural transformation is linked to low agricultural productivity and consumption deficits in rural areas. This is due to the formation of households at a young age and an increase in the proportion of marriages has increased the number of households over time. Children born to one father have actually formed a group of villages (household groups). Of the 11,749,925 households in rural Ethiopia, 56 percent of them are households of many children and the rest of them are many labor households. Many children's households have higher consumption requirements and lower economic support ratios. The number of households of many children increases consumption and land requirements. Meanwhile, agricultural labor productivity in rural Ethiopia remained at the same level for decades despite the growth of rice production. Rice production growth is a result of increased inputs (especially land), and not because of technological advances and institutional innovation (Teganu, 2011). 
The third reason why Ethiopia requires structural transformation is because of the geo-political situation. The fourth reason is related to the increasing trend of globalization, especially the improvement of worldwide communication system and the current economic condition, high mobility especially from financial resources and trade. To take advantage of the greater opportunities created by the global market the economic structure of Ethiopia must change and focus on some kind of specialization. On the other hand, the facts show that developed countries, such as members of the OECD and some countries such as Turkey, Malaysia, China and other emerging economies, are successful in carrying out their structural economic transformation. Namely a country that in the early days of livelihood most of the population and its economy relied on the primary sector. In a relatively short period of time (25-50 years), most of the people and economies depend on the secondary sector and the productive, competitive and sustainable tertiary sector. For example, at the beginning of the construction period, about 40-70 per cent of the population of OECD countries (USA, Canada, Western Europe, Japan, South Korea, Australia and New Zealand) work in agriculture, forestry and fisheries. The contribution of this primary sector to GDP is about 40 - 75 percent. After becoming a developed country, the people who work in agriculture, forestry and fisheries are no more than 15 percent of the total population. While the contribution of these three primary sectors to GDP is still quite large which is about 20 - 45 percent. The majority of the population and its economy turn to the more productive and competitive sectors of secondary and tertiary.

Growth and its determinants: Economic growth is a process of per capita output growth over the long term, in the other sense that economic growth is the process of increasing the production of goods and services in the economic activities of a society (Yunan, 2009). Economic growth is the process of changing a country's economic conditions on a sustainable basis to a better state over a certain period. Economic growth can also be interpreted as a process of increasing the production capacity of an economy that is realized in the form of an increase in national income. The existence of economic growth is an indication of the success of economic development (Sitindaon, 2013). Meanwhile, according to Josep Schumpeter in Sitindaon (2013), economic growth occurs when there is innovation from entrepreneurs (entrepreneurs). In this case, innovation is the application of new knowledge and technology in the business world. Innovation has the effect of introducing new technologies, generating higher profits, leading to imitation of innovation, the imitation of new technology by other entrepreneurs who can increase their production. Judging from the Neo Classical economic growth, the Model pioneered by Stein in 1964, later developed further by Roman and Siebert. According to this theory, regional economic growth will be greatly determined by the ability of the region to increase its production, while the regional production activities are not only determined by the potential of the region concerned, but also the mobility of labor and inter-regional capital mobility. Classical Neo followers assume that the mobility of factors of production, both capital and labor, at the beginning of the development process substandard. Consequently, at that time capital and skilled labor tends to be concentrated in more developed areas so the economic growth gap tends to widen (Sitindaon, 2013).

Meanwhile, according to the view of classical economists, there are 4 factors affecting economic growth, namely population, stock of capital goods, land area and natural wealth, and the level of technology used. The classical economists who gave his opinion on economic growth were:

- Adam Smith, that economic growth is characterized by two interrelated factors namely population growth and total output growth. Growth of output achieved is influenced by natural resources, labor (population growth), and the amount of inventory.

- David Ricardo and T.R Malthus, that the increasing population growth factor doubled at a time will lead to abundant labor. Ricardo's opinion is in line with the theory put forward by Thomas Robert Malthus, stating that food (production) will increase according to the count arithmetic (one, two, and so on). While the population will increase according to geometrical progression (one, two, four, eight, sixteen, and so on) so that at some point the economy will be at the level of subisten or stagnation. (Sitindaon, 2013)

Simon Kuznet in Masli (Accessed 2016) defines economic growth as the capacity of a country to provide economic goods for its population, the growth of this capability is due to technological advancement, institutionalization and the necessary ideological adjustment. The results showed that simultaneously bank kerdit, export value, government expenditure, and the amount of labor significantly influence the growth of Indonesian economy at 99\% (@ = 1\%) confidence level with coefficient of determination (R2) of 98,46\%. 
While partially the result of analysis indicate that bank credit, government expenditure, and number of labor have positive effect to economic growth in Indonesia. This means that Indonesia's economic growth will increase significantly with the increase of bank credit, government expenditure, and the amount of labor, while export value has no significant effect (Yunan, 2009). Concludes that factors affecting economic growth are (1) Manpower defined as people aged 15 years or older who work, find work, and are doing other activities, (2) Dependency ratio is defined as the ratio between groups The population aged 0-14 years who are not economically productive and the population aged 65 years and over belong to a group of nonproductive people with the age group of 15-64 years included in the productive group. Population growth is a population change at any time, and can be calculated as a change in the number of individuals in a population using "per unit time" for measurement. Population growth is one of the important factors in general socioeconomic problems and population problems in particular. Because in addition to affect the number and composition of the population will also affect the socio-economic conditions of an area or country and the world ( Sitindaon, 2013).

Growth and Government Fiscal Policy: In general, fiscal policy is understood as a policy made by the government to direct the economy of a country through government expenditures and revenues (in the form of taxes). Changes in the level and composition of taxes and government expenditures may affect aggregate demand variables and levels of economic activity, variable resource dispersion patterns, and income distribution variables. The government's fiscal policy is aimed at influencing the economy or with the government's fiscal policy trying to steer the economy toward its desired state. Through fiscal policy, governments can influence the level of national income, employment, national investment, and may affect the distribution of national income. The function of fiscal policy is a stabilizer instrument in maintaining the economic stability, consistent evidence of the fiscal policy impact on the economic growth is through the structure of government revenue and expenditure management, so that it can develop the economic growth (Sirait, 2013). Fiscal policy is certainly different from monetary policy, which aims to stabilize the economy by controlling the interest rate and the amount of money in circulation. Based on this, we can understand that the main instruments of fiscal policy are expenditure and taxes. Fiscal policy is the implementation of the operational form of government budget policy in managing state finances. The policy direction emphasizes the allocation of state expenditure and state revenue, especially taxation. For example high taxes, or even tax exemptions in the control of the economy to achieve national goals. The objectives of fiscal policy are to stimulate and encourage economic growth, to control economic stability, to create social justice for society, to expand and create employment, to realize the distribution and distribution of income and to prevent unemployment and to maintain price stability (Financial Note and State Budget Development Plan, 2015).

The focus of the discussion is how government fiscal policy can efficiently allocate budgets on capital accumulation and labor supply. In this general model, the growth rate and the level of government fiscal policy can affect output growth. There are empirical test models using cross-section data in 107 countries. Empirical results using data on growth rates during the period 1970-1985 show the significant and negative impacts of government fiscal activity on the output growth rate both in the short and long term (Engen and Skinner, 1992). In a study of the impact of tax increases on output growth (Aziz, 2016), 10 percent tax increase is predicted to reduce output growth by 3.2 percent per year. Large long-term effects also occur in expenditures where a 10 percent increase in budget is expected to reduce output growth by 1.4 percent per year. Thus, the study proves that government spending, tax rates will have the greatest long-term negative impact on private sector productivity.

Implementation of Fiscal Policy in Agricultural Sector: The Central Bureau of Statistics (BPS) has published some data on agriculture census results in 2013, which revealed that in 2003 Indonesia's food imports only reached US $\$ 3.34$ billion, but 10 years later or in the 2013 census implemented it has risen more than Quadrupling to US \$ 14.90 billion. The data above becomes one indication that Indonesia has not succeeded in realizing food self-sufficiency. Rising food imports are among others attributable to: (1) increased consumption of Indonesian food, (2) increasing population of Indonesia. The conclusion is based on data from the National Population and Family Planning Agency (BKKBN) in 2012 which states that the estimated population of Indonesia in 2013 is 250 million people and by 2025 the population of Indonesia is expected to reach 400 million (Aziz, 2016). Some of the fiscal policies that have been and are being 
implemented by the Indonesian government in order to reduce the problems in the agricultural sector are as follows:

Credit Program: In the past decade, the Indonesian government has actually tried its best to revitalize this sector of agricultural financing. The Government has rolled out various credit models that are divided into two models of credit financing schemes, risk guarantee schemes and interest subsidy schemes. Agricultural credit under a default risk guarantee scheme (in this case the people's business credit program) is intended for prospective borrowers who have not-bankable but feasible characteristics. This credit is intended for prospective borrowers who have not met the credit / financing requirements of the implementing bank as reflected in the provision of collateral and other credit requirements / financing in accordance with the provisions of the implementing bank. However, at the same time the debtor is deemed to have been feasible because it has a business which is expected to provide a profit so that it is considered will be able to pay interest and return the entire principal loan obligations within the agreed time period between the executing bank and the debtor. Meanwhile, agricultural credit with interest subsidy scheme is credit given to prospective borrowers who have fulfilled loan / financing requirements from implementing bank as reflected in the provision of collateral and fulfillment of credit requirements / financing in accordance with the provisions of the implementing bank. However, at the same time the business is considered not yet able to provide profit to pay interest and return all the principal loan obligations in the agreed time period between the executing bank and the debtor. This condition is the government's consideration to provide interest subsidy (with certain amount) to the debtor. (Aziz, 2016)

Agriculture Insurance: The agricultural sector is one sector that still plays an important role in Indonesia. Based on current prices until 2012, this sector contributes a GDP output value of Rp1.190 trillion or about 14.44 percent of total GDP of about Rp8,241 trillion. This sector is also still able to absorb the workforce of Indonesia about 39.96 million inhabitants. Every Indonesian farmer is entitled to protection in the face of all problems such as price risk, crop failure, high cost economy practice, and climate change. This is one of the principles mandated in Law Number 19 Year 2013 on Farmers Protection and Empowerment. The character of business in the agricultural sector will usually encounter very high uncertainty risks such as natural disasters such as floods, drought, pest attacks, climate change factors, as well as the certainty of risk of market price fluctuations in these commodities. This if left further will affect the stability of national food security (Aziz, 2016).

Infrastructure Spending In Agriculture: The government actually has a lot to play in the development of the agricultural sector, one of which is the procurement of agricultural equipment and agricultural infrastructure development in Indonesia. One of the infrastructure that is the focus of the government is the irrigation infrastructure where in the condition up to 2012 the irrigation infrastructure network in Indonesia is currently 7.23 million hectares according to data from the Ministry of Public Works, from the data it turns out there are only about 4.41 million hectares Irrigation networks that are still in good condition (Aziz, 2016).

\section{Methodology}

The research methodology used to answer the main objectives of this study is a combination of methods:

- Exploration of theory and implementation in other developing countries related to structural transformation, economic growth, fiscal policy, and others. In this study, the authors take examples of cases in the countries of Vietnam, Ethiopia and OECD countries to compare with the transformation of the agricultural sector to be lesson learned.

- Analysis of economic data such as GDP and Indonesian labor and cases in the countries of Vietnam, Ethiopia and OECD countries to be mapped according to indicators of Strength, Weakness, Opportunity and Threat (SWOT) in order to find the right policy solution.

\section{Results and Discussion}

The biggest challenge of the economy in the current era of globalization is how to make the Indonesian population prosperous, let alone Indonesia has a very large population. The population of Indonesia is 252.16 million people (BPS, 2013). This large population is a major consideration of the central and local 
governments, so that the direction of the Indonesian economy is built to meet the food needs of its people. Based on this consideration, the agricultural sector becomes an important sector in the structure of the Indonesian economy. However, this sector is currently getting less serious attention from the government. One of them is the lack of protection of farmers from the importation of agricultural goods, the low credit for the agricultural sector and some other policies that do not provide optimal benefits for the agricultural sector. In addition, there are still many agricultural development programs that are not directional and not optimal.

The Impact of Structural Transformation: The course of agricultural development in Indonesia to date has not yet been able to show maximum results. This is evident from the level of farmers' welfare and contribution to national income. Therefore, agricultural development in Indonesia is an important development of the overall national development. There are several reasons why agriculture development in Indonesia plays an important role, partly because of the huge and diverse potential of natural resources, its contribution to substantial national income, its contribution to national exports is also considerable. In addition, the large population of Indonesia is dependent on this sector and its role in the provision of community food and become the basis of growth in the countryside. However, Indonesia's huge agricultural potential, in fact until now most of its farmers are still classified as poor. In the introduction section has been discussed that there is an indication of structural transformation in the Indonesian economy due to changes or shifts in the contribution of each sector of the Indonesian economy in the formation of GDP. In Table 1 below is a complete picture of the process of structural transformation of the economy of 2000 to 2015. In the table it can be shown that the agricultural sector from year to year has decreased consistent and significant contribution. This indicates if this condition is left alone or there is no maximum effort from the government then the contribution of this sector in the next 50 years will be zero. The problem that arises is not just the value of its contribution to GDP, but to be noticed is the potential for huge unemployment in Indonesia if the agricultural sector is allowed to collapse, because this sector can accommodate nearly 40 percent of the total workforce in Indonesia. At the same time the eight other sectors of the economy need more assistance from human resources (except the mining sector) so that it can be ascertained to the other eight sectors can not absorb labor migration from the agricultural sector. The following Table 1 shows the contribution of each sector to GDP from 2000 to 2015. The agricultural sector shows a downward trend.

Table 1: Sectoral Contribution on Indonesian GDP (Constant Price) 2000 - 2015 (\%)

\begin{tabular}{|c|c|c|c|c|c|c|c|c|}
\hline Sector & 2000 & 2005 & 2010 & 2011 & 2012 & 2013 & 2014 & $\left.2015^{*}\right)$ \\
\hline Agriculture & 15.60 & 14.50 & 13.17 & 12.78 & 12.53 & 12.26 & 12.06 & 12.18 \\
\hline Mining & 12.07 & 9.44 & 8.09 & 7.72 & 7.37 & 7.07 & 6.72 & 6.74 \\
\hline Industry & 27.75 & 28.08 & 25.80 & 25.72 & 25.59 & 25.55 & 25.50 & 25.46 \\
\hline Electric, Gas, etc & 0.60 & 0.66 & 0.78 & 0.77 & 0.77 & 0.77 & 0.77 & 0.79 \\
\hline Construction & 5.51 & 5.92 & 6.48 & 6.46 & 6.52 & 6.58 & 6.67 & 6.69 \\
\hline Trade, Hotel, ets & 16.15 & 16.77 & 17.30 & 17.75 & 18.07 & 18.09 & 18.02 & 18.06 \\
\hline Transport, etc & 4.68 & 6.24 & 9.42 & 9.79 & 10.13 & 10.52 & 10.95 & 10.78 \\
\hline Finance, etc & 8.31 & 9.21 & 9.55 & 9.58 & 9.66 & 9.83 & 9.91 & 9.90 \\
\hline Services & 9.34 & 9.18 & 9.41 & 9.44 & 9.35 & 9.32 & 9.40 & 9.39 \\
\hline
\end{tabular}

Source: BPS-Statistics Indonesia, 2015; *) Projection, Data Prosessed

If this really happens then in the next 50 years Indonesia will experience a tremendous economic crisis caused by social and financial problems due to the huge unemployment rate. The current structural economic transformation in Indonesia will sooner or later affect the overall economic condition of Indonesia, both macro and micro. In fact, structural transformation is a matter already discussed by (Todaro, 1991) that this condition will inevitably occur in developing countries, namely the transition from an earlier subsistence economy and focusing on the agricultural sector to a more modern and highly dominated economic structure Industry and services sectors. The sectors most affected by the structural transformation are the composition of the persector labor and the income composition of the per capita of the sector. 
Composition of Labor Persector: According to (Herrendorf et al., 2013) that structural transformation must be related to 3 basic problems, two of which are about the transfer of labor and added value to GDP. Our labor structure is still dominated by agricultural sector around 32.87 percent (BPS-Statistics Indonesia, 2015), followed by trade, hotel and restaurant sector at 22.37 percent, and service sector at 15.60 percent. The average proportion of labor from 2000 to 2015 for the agricultural sector was 36.69 percent, while the trade and other sectors were 21.21 percent, and the manufacturing industry had an average proportion of 12.96 percent. This can be seen in Table 2 below. This data shows the important role of the agricultural sector which is the sector where the majority of Indonesian workers depend on their income to live. Proportionally the amount of labor in the agricultural sector is still the largest. On the other hand, when viewed from the trend of the number of manpower in the agricultural sector from year to year both percentage and nominal it can be explained that the workforce in this sector continues to experience a significant decline. As shown in Graph 1 below.

Table 2: Indonesian Labour by Major Sector 2000 - 2015 (In Percentage/Portion of Total)

\begin{tabular}{|c|c|c|c|c|c|c|c|c|}
\hline Sector & 2000 & 2010 & 2011 & 2012 & 2013 & 2014 & 2015 & Average \\
\hline Agriculture & 45,28 & 38,35 & 36,39 & 35,19 & 34,78 & 34,00 & 32,88 & 36,69 \\
\hline Mining & 0,50 & 1,16 & 1,34 & 1,42 & 1,27 & 1,25 & 1,15 & 1,16 \\
\hline Industry & 12,96 & 12,78 & 13,54 & 13,88 & 13,27 & 13,31 & 13,29 & 13,29 \\
\hline $\begin{array}{l}\text { Electricity, Gas, and } \\
\text { Water }\end{array}$ & 0,08 & 0,22 & 0,22 & 0,22 & 0,22 & 0,25 & 0,25 & 0,21 \\
\hline Construction & 3,89 & 5,17 & 5,83 & 6,09 & 5,63 & 6,35 & 7,15 & 5,73 \\
\hline $\begin{array}{l}\text { Trade, Restaurant and } \\
\text { Hotel }\end{array}$ & 20,58 & 20,79 & 20,76 & 20,90 & 21,38 & 21,66 & 22,37 & 21,21 \\
\hline $\begin{array}{l}\text { Transport, Storage and } \\
\text { ets }\end{array}$ & 5,07 & 5,19 & 4,66 & 4,49 & 4,52 & 4,46 & 4,45 & 4,69 \\
\hline Financial Institutions, etc & 0,98 & 1,61 & 2,40 & 2,40 & 2,57 & 2,64 & 2,84 & 2,21 \\
\hline Community Service, etc & 10,66 & 14,75 & 14,87 & 15,40 & 16,36 & 16,07 & 15,62 & 14,82 \\
\hline Total & 100,00 & 100,00 & 100,00 & 100,00 & 100,00 & 100,00 & 100,00 & 100,00 \\
\hline
\end{tabular}

Source: National Labor Force Survey, BPS-Statistics Indonesia, 2015. Data prosessed

Grafic 1: Indonesian Labour by Major Sector 2000 - 2015 (In Million People)

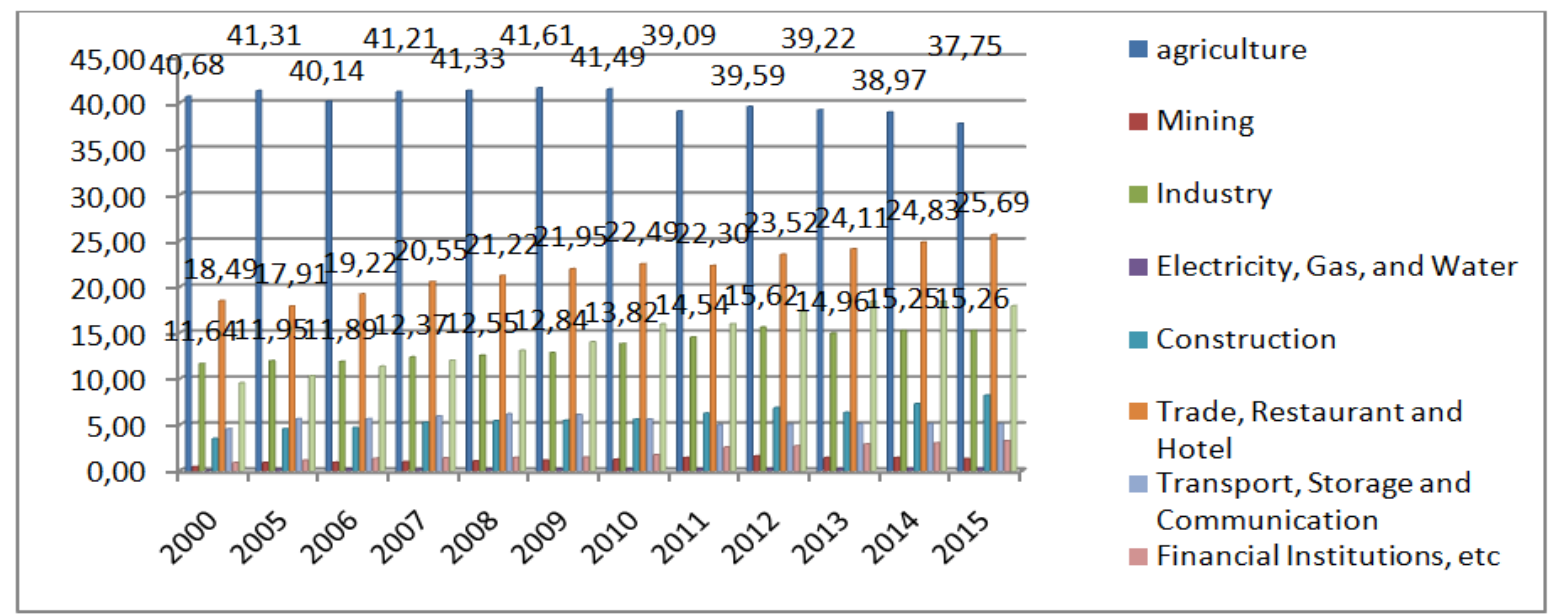

Source: National Labor Force Survey, BPS-Statistics Indonesia, 2015

For example, in 2010, the proportion of labor in the agricultural sector reached 38.35 percent with a nominal amount of 41.49 million workers. However, in 2015 the number dropped dramatically to 32.88 percent or there are about 3.74 million within 5 years. Meanwhile, in the same period, there was a significant increase in the trade sector from 22.49 million workers (in 2010) to 25.68 million people working in this sector. 
Similarly, in the industrial sector from 13.82 million people (2010) to 15.25 million people (2015), the services sector is from 1.7 million people (2010) to 3.26 million people (2015) and the sector From 15.97 million people (2010) to 17.93 million people. The authors are very confident that there is a shift of labor from the agricultural sector to the other four sectors (trade, industry, services, and financial sectors.

Composition of Perkapita Persector Revenue: Table 3 below illustrates the composition of per capita income in Indonesia for the last 15 years between 2000 and 2015. In Table 3 and Graph 2 it can be seen that, per capita income for labor employed in agricultural sector is still very low compared to other sectors. Although from year to year shows the numbers that continue to rise but the nominal increase is not so significant. Up to 2015, per capita income in this sector is only Rp9.40 million. The difference is so far as per capita income in other sectors (especially mining, transport, finance, electricity and industry). This is what then makes the agricultural sector abandoned by its workforce to move in other sectors.

Table 3: Income Composition of Per Capita Economic Sector (in millions of rupiah)

\begin{tabular}{|c|c|c|c|c|c|c|c|c|c|c|c|c|}
\hline Sector & 2000 & 2005 & 2006 & 2007 & 2008 & 2009 & 2010 & 2011 & 2012 & 2013 & 2014 & 2015 \\
\hline Agriculture & 5,33 & 6,15 & 6,54 & 6,59 & 6,89 & 7,11 & 7,34 & 8,06 & 8,29 & 8,66 & 9,00 & 9,40 \\
\hline Mining & 371,06 & 182,73 & 181,93 & 172,21 & 161,13 & 155,99 & 149,18 & 132,51 & 120,51 & 137,30 & 136,05 & 148,67 \\
\hline Industry & 46,22 & 41,12 & 43,24 & 43,50 & 44,45 & 44,40 & 43,19 & 43,58 & 42,92 & 47,29 & 48,63 & 48,58 \\
\hline $\begin{array}{l}\text { Electricity, Gas, } \\
\text { and etc }\end{array}$ & 118,84 & 59,51 & 53,73 & 77,29 & 74,56 & 76,83 & 77,11 & 80,65 & 80,00 & 84,30 & 77,54 & 79,42 \\
\hline Construction & 21,90 & 22,69 & 23,89 & 23,19 & 24,09 & 25,56 & 26,82 & 25,40 & 24,94 & 28,68 & 26,66 & 23,72 \\
\hline Trade, etc & 12,14 & 16,40 & 16,26 & 16,56 & 17,14 & 16,79 & 17,81 & 19,62 & 20,12 & 20,78 & 21,12 & 20,47 \\
\hline $\begin{array}{l}\text { Transport, } \\
\text { Storage and } \\
\text { Communication }\end{array}$ & 14,28 & 19,33 & 22,04 & 23,89 & 26,85 & 31,42 & 38,79 & 48,20 & 52,53 & 57,17 & 62,30 & 61,47 \\
\hline Finance, ets & 130,82 & 141,22 & 126,35 & 131,23 & 136,17 & 140,70 & 127,06 & 91,61 & 93,84 & 93,90 & 95,13 & 88,26 \\
\hline $\begin{array}{l}\text { Community } \\
\text { Service, etc }\end{array}$ & 13,55 & 15,57 & 15,03 & 15,12 & 14,74 & 14,67 & 13,65 & 14,57 & 14,13 & 13,99 & 14,85 & 15,23 \\
\hline
\end{tabular}

Source: National Labour Force Survey and GDP BPS 2015 / Indonesian National Statistic Board: 2015, Data Prosessed

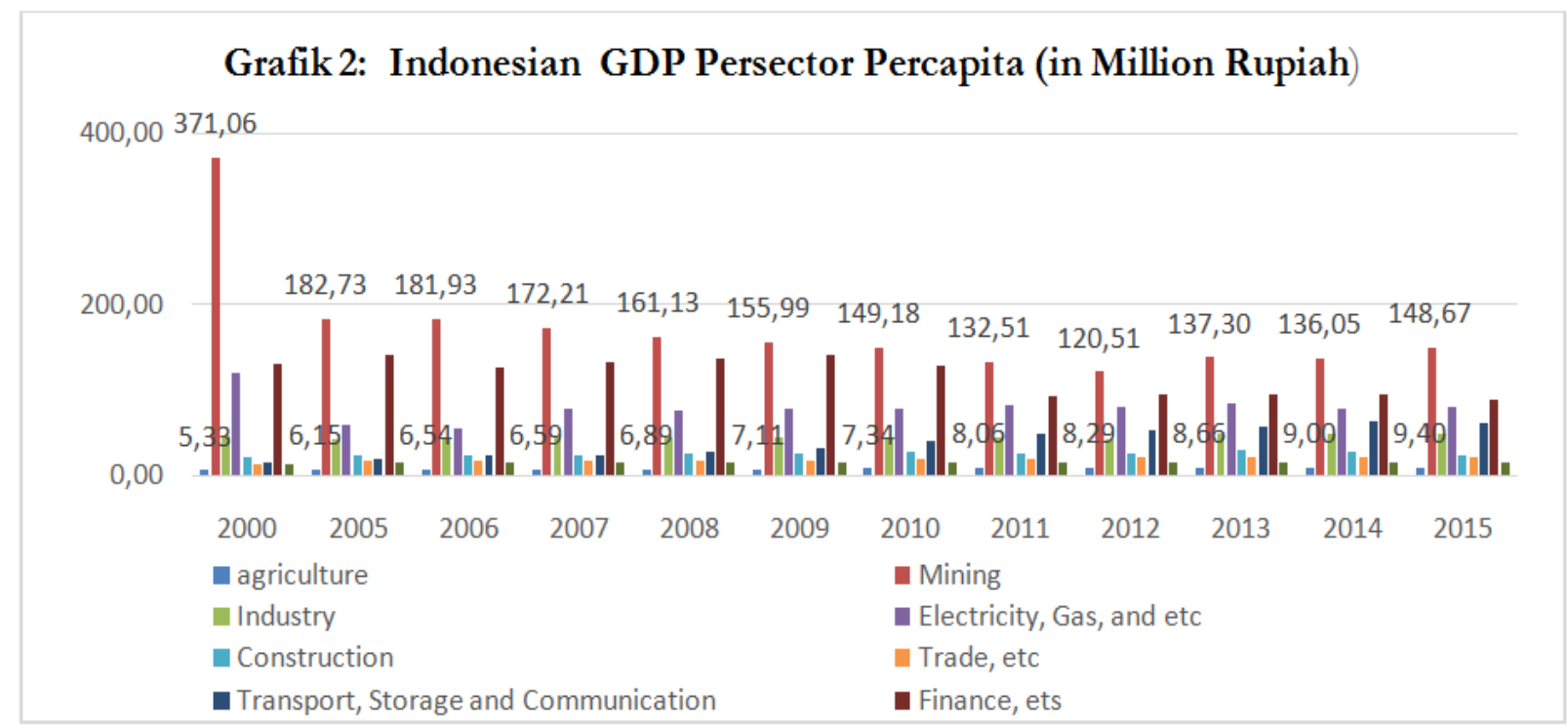

Source: National Labour Force Survey and GDP BPS 2015 /BPS-Statistics Indonesia, 2015, Data Posessed 
The unfavorable condition of Indonesia's economic structure is caused by the leapfrog of Indonesia's economic structural transformation from the primary economic structure based on natural resources, namely the agriculture and mining sectors directly to the tertiary economic structure (third) such as trade and transportation sector. This has the potential to cause shocks to the national economy which has an effect on the slow economic growth. The slowdown in economic growth is also caused by several things, among others, the basic capital of economic development in the not ready condition such as the availability of human resources (labor) and technology. Structural transformation will have the potential to achieve success if the shift runs gradually ie by not leaving the structure of secondary economy / industrialization. When the industrialization stage has been achieved well and strongly, structural transformation towards a higher stage such as the trade and other tertiary sectors will result in more inclusive economic growth. This inclusive economic growth is expected to encourage the acceleration of economic development that will be felt by the wider community. In line with the occurrence of this structural transformation, the Indonesian agricultural sector is experiencing problems in increasing the amount of food production. This is because the narrowness of agricultural land is being used. Increasing population growth makes the need for land for residence and various means of life support community also increases. The development of industry also makes agriculture irrigation technical decreasing. In addition, the level of agricultural productivity per hectare is also relatively stagnant. One of the causes of this productivity is that the water supply to irrigate agricultural land is also reduced. Therefore, many reservoirs, dams, waterways and irrigation systems still need to be repaired.

SWOT analysis: If you see the character of a developing country from the geo-political, social, security, economic, natural and human resources, then things that happen in Vietnam and Ethiopia (as discussed in the above section) are also likely to occur In Indonesia, such as the enormous increase in labor force in each year, the tendency to transfer the profession to other sectors by leaving the agricultural sector, and others. This should be the government's concern to prepare fiscal and non-fiscal strategic measures and policies in order for this process of structural transformation to generate inclusive economic growth. That is, economic growth that can be felt widely by the entire population and felt by all parties. It is the Government's duty to manage this shift in structural transformation, thus not the beginning of the economic crisis and the destruction of the national economy. These strategic measures and policies could start from the SWOT analysis of the agricultural sector as the authors show below.

\section{Tabel 4: SWOT Analysis}

\begin{tabular}{ll}
\hline Strengths & Weakness \\
\hline Have a large contribution potential in GDP & Positioned not as a Priority sector \\
Absorbs large workforce & Vulnerable to Climate Change \\
Provider of food (primary needs) for the & $\begin{array}{l}\text { The Difficultness of Financing Acsebilitas for the } \\
\text { population }\end{array}$ \\
perpetrator
\end{tabular}

\section{Opportunities}

Opening employment

Extremely wide farmland

Potential Natural resources are very large

\section{Threats}

1. The existence of green growth challenge

2. Impact of Regional Autonomy Policy

3. Accessibility difficulties get agricultural input support

4. The existence of global competition and open market

\section{Source: Illustration Writer}

Many roles and contributions of the agricultural sector to the Indonesian economy, so the sector is still urgent to continue to be built and developed. There are 4 key variables to overcome the problems of agricultural sector transformation. The key is how the government can take an optimal and strategic role through the optimization of fiscal policies that have been implemented so far such as credit programs for the people, agricultural insurance programs, and infrastructure finance programs. Another thing is how the government can maximize the advantages and opportunities of this agricultural sector and can reduce the weaknesses and obstacles that occur, for example through some programs and policies. One such policy is to provide easy access to financing and capital for farmers, improvement and development of agricultural infrastructure such as dams, reservoirs, irrigation canals, and others. In addition, the government should provide ease of market access for farmers to sell their products at harvest time, such as export access. It also encourages and focuses 
superior research activities optimally in searching for superior plant seeds, bio agricultural technology, fertilizers, agricultural and other engineering improvements.

One of the policies to be taken is to scale up program priorities and to strengthen linkages, roles and alignment of programs between institutions and other institutions, to make fiscal and non-fiscal policies in the sectors of agriculture pro-people such as targeted subsidies. Another thing is to continuously improve cooperation between central and local government, industry sector and research and development institutes or universities to realize food self-sufficiency in Indonesia. Including controlling the implementation of agricultural land conversion to other needs/life sectors, as well as improving and encouraging a conducive investment climate in agriculture. In addition, the task and role of the government is no less important is to provide subsidies for agricultural output, for example by buying rice farmers at a price above market prices so that income and welfare of farmers increases, oversee the course of regional autonomy in order not to harm the agricultural sector and always encourage the synergy between development Agricultural sector and green economic growth. In the end how fiscal policies or development programs that the government promotes can boost output growth (economic growth) rather than vice versa, the implementation of fiscal policy or other development programs actually degrade the economic growth as discussed by Engen and Skinner (1992) in the previous section. The point is how to make fiscal policy one of the saviors and guards of a structural transformation that is detrimental to a sector in this case is the agricultural sector, and how to implement government policies that support a more inclusive economic growth where the results can be perceived by all groups community.

\section{Conclusion and Recommendations}

The Indonesian economy as well as other emerging economies are currently undergoing structural transformation from the agricultural sector to industrial sectors, services and trade. The average labor sectors that contribute in the agricultural sector from 2000 to 2015 are still quite dominant at 36.69 percent. The task of the government is to maintain the structural transformation with appropriate fiscal policy and development programs to avoid potential negative impacts. One of the development programs that can be recommended as a result of the transformation of the agricultural sector in Indonesia is to encourage more inclusive economic growth. Several fiscal policy instruments that can be applied include the provision of credit programs such as Credit for Business program, Investment Credit and Credit for Food Security and Energy. In addition, subsidies in agriculture such as credit interest subsidies, fertilizer subsidies and seed subsidies to farmers can also be provided. Likewise can be applied agricultural insurance schemes, programs to increase infrastructure spending in agriculture, giving easy access to banking for farmers and the ease of licensing for entrepreneurs in the field of agriculture.

\section{References}

Aziz, A. (2016). Analysis of Utilization of Sharia Product Investment in Agricultural Sector in Indonesia, Fertility Policy Book of Fertilizer and Food Security, Fiscal Policy Agency, Ministry of Finance of Indonesia

Engen, E. M. \& Skinner, J. (1992). Fiscal Policy and Economic Growth, NBER Working Paper Series. Working Paper Number 4223. December. 1992. available online at http://econ.tu.ac.th/class/archan/Sakonpaper.pdf

Financial Notes and Revenue and Expenditure Budget Plan for Fiscal Year. (2015). Ministry of Finance of the Republic of Indonesia, available online at http://www.kemenkeu.go.id/sites/default/files/Subkatalogdata/NK\%20RAPBN\%202015\%20web. pdf

Herrendorf, B., Rogerson, R. \& Valentinyi, A. (2013). Growth and Structural Transformation, NBER Working Paper No. 18996, April 2013, available online at https://www.imf.org/external/np/seminars/ eng / 2013 / SPR / pdf / rrog2.pdf

Kariyasa, K. (2017). Changes in Economic Structure and Employment Opportunities and Quality of Human Resources In Indonesia, Available Online. Accessed 2017 At https://www.scribd.com/doc/100738672/change-Structure-Economy-Dan-Accportunity-work Serta-Quality-Sdm \#; 
Masli. (2016). Analysis of Factors Affecting Economic Growth and Regional Inequality between Districts / Cities in West Java Province, hevailable online at http://www.stan-im.ac.id/jsma/pdf. (Accessed 2016)

Mc Caig, B. \& Pavcnik, N. (2013). Moving out of Agriculture: Structural Change in Vietnam, available online at https://www.dartmouth.edu/ npavcnik/docs/Vietnam_structural_change_October_2013.pdf

Sirait, Y. \& Magdalena. (2013). Analysis on Fiscal Policy Impact to Indonesian Economic Growth, Faculty of Economy of the Jember University. Jember. East Java Indonesia.

Sitindaon, D. (2013). Factors Affecting Economic Growth in Demak Regency. Thesis. Faculty of Economics. State University of Semarang. Indonesia.

Statistics Indonesia. (2015). National Labour Force Survey and Gross Domestic Product.

Sudarmono, M. (2006). Analysis of Structural Transformation. Economic Growth and Regional Inequality in Development Area in Central Java. Thesis. Diponegoro University. Semarang. Indonesia

Teganu, T. (2011). Structural Transformation is a Defining Moment that Leads Ethiopia to Modern Development, available online at https://www.diva-portal.org/ smash / get / diva2: 938611 / fulltext01.pdf.

Todaro, M. P. (1991). Economic Development of the Third World, 4th Edition, Hyderabad, India: Oriental Longman Limited.

Yunan. (2009). Analysis of Factors Affecting Economic Growth Indonesia. Thesis. University of North Sumatra. Medan. Indonesia, available online at http://mfile.narotama.ac.id/files/Zakki\%20Falani/Temp/10E00031.pdf. 